\title{
Exploration and Characterization of "Uwi" Plant (Dioscorea sp.) in East Java Uplands, Indonesia
}

\author{
Wuryantoro Wuryantoro ${ }^{1, *}$, Ratna Mustika Wardhani ${ }^{1}$, Indah Rekyani Puspitawati ${ }^{1}$, \\ Praptiningsih Gamawati Adinurani ${ }^{1}$, and Bohari Mohammad Yamin ${ }^{2}$ \\ ${ }^{1}$ Department of Agrotechnology, Faculty of Agriculture, Merdeka University of Madiun, \\ Jl. Serayu no.79, Madiun City 63133, East Java, Indonesia \\ ${ }^{2}$ Department of Chemistry, Faculty of Science and Technology, Kebangsaan University of Malaysia, \\ 43600 UKM, 43600 Bangi, Selangor, Malaysia
}

\begin{abstract}
Uwi" (Dioscorea sp.) is a tuber plant species with potentials to support the national food diversity program because it has high tolerance when planted in upland areas, which are wide in Indonesia and beyond. The study aims to rescue germplasm of "Uwi" plants through exploration, identification, and collection for the sake of national long-term goal of providing alternative food sources to support food security. The research began with exploration of the west upland area of East Java, and continued with specimen planting for characterization testing in the following year. Exploration resulted in 127 samples of variants observed throughout uplands in Madiun, Ponorogo, Ngawi, Magetan and Pacitan, East Java, Indonesia with each result of 28, 26, 9, 20 and 44 variants. Five big groups of Dioscorea family namely Dioscorea alata, Dioscorea aculeata, Dioscorea hispida, Dioscorea pentaphylla and Dioscorea bulbifera were mapped out as a result. Using SPSS cluster analysis, D. alata as the most variant were specified into 20 groups and further gathered into seven clusters based on its main botanical characteristics of leaf shape, leaf color, stem color, tuber color, tuber shape, and skin color of the tuber. Meanwhile, D. aculeata and D. pentaphylla were each detailed into two sub-clusters and other types were each detailed into one.
\end{abstract}

Key words: Characterization, cluster analysis, food securiy, germ plasm, tubers plant potentials

\footnotetext{
* Corresponding author: wuryantoro@,unmer-madiun.ac.id
}

\section{Introduction}

Indonesia's food provision is deteriorating due to the vast functional shift of agricultural land nationwide, and it has gone so low that even the international Food and Agriculture Organization (FAO) considers it serious in the global hunger index. It is said that there will be food scarcity in near future as a result of various events, such as environmental damage, land conversion, high fossil fuel prices, and climate change. In fact, the nation's critical land area has reached 24303294 ha [1] and continues to grow. Food is an essential need, and therefore requires intense implementation to secure it.

One critical problem currently exists in Indonesia regarding major food commodity is the high reliance on rice - it is so high that scarcity often occurs. This is not the case in ancient times. Back then, not all regions in Indonesia consumed rice since many of them were affixed to their local staples. That Indonesia is naturally an archipelagic country with a variety of ecosystems actually makes it perfect for staple diversification. Most staple foods are carbohydrate-based due to its fulfilling and energizing effect, thus the reason $\mathrm{w}-$ hy rice 
is popular. Its domination, however, diminish the chance of other commodities to grow; the low development on other carbohydrate-based sources is evident. Considering that food security relations and sustainable agriculture development using local planning will result in multidimensional roles and impact food security in terms of availability, access, and utilization [2], attempts made to increase food self-sufficiency should not only be focused on rice and wheat, but also be supported by other types of strategic commodities, e.g. tubers, food-producing trees - like sago (Metroxylon sagu Rottb), bread fruit [Artocarpus altilis (Parkinson) Fosberg], "aren" [Arenga pinnata (Wurmb) Merr.] - and other multipurpose plant species. When consumption is generated from various sources and, at the same time, specific food source commodities are maintained, food security shall be steady. There is no single food ingredient in the world that contains all the nutrients human body needs ideally. In order to meet the nutritional needs, people should also consume carbohydrate sources other than rice. There are many types and variety of potential bulbs spread all nationwide over as alternative food for rice substitute. Researches on food, therefore, should emphasize more on its availability, accessibility, and security. Study [5] shows that food provision in accordance with each region's potential based on what is available in each respective region will greatly facilitate the community in meeting their needs. Compared to rice cultivation, which tends to exploit irrigated land leading to quick land deterioration, upland (non irrigation) cultivation should be capable of not only supporting non-rice diversification food products, but also protecting the environment, with proper management and adequate cultivation system. What occurs in Beneue State of Nigeria [9], where yam is the main staple food consumption as well as source of income and employment generation, can occur in Indonesia, too.

"Uwi" plant (later referred as "uwi"), due to its tolerant nature to grow upland and its high productivity, is a potential source of carbohydrate in food diversification. A member of the genus Dioscorea, it is generally a climbing shrub with heart-shaped leaves. Producing tubers in the soil, some may also have hanging (aerial) ones. To obtain high production, planting at the beginning of the season is highly recommended $[11,12]$. Result of Boutau Yam (D. alata) study indicates that the optimum harvesting time is the ninth month after sowing, since it gives the highest value of energy, carbohydrates, and dry matters [14]. The research shows that in Nigeria, the production and consumption of "uwi" continued to increase from 1996 to 2006 with a relative increase of more than $400 \%$, indicating the potential of "uwi" as food for the future is getting more important [10]. Production was majorly constrained by lack of capital, scarcity/high cost of seed yams, high cost of labor, and pests and diseases infestation [13]. Research in Madiun residence, East Java, Indonesia also shows that $D$. alata is the type with the most diversity and a broad distribution [15].

The high diversity in "uwi" should allow production of various types of processed foods. These non-rice plants, after processed into flour, can take part as an analog rice material. Their nutritional values, combined with other materials, should be adjustable to suit various preferences. For illustration, "uwi" bulb contains low glycemic index value the way analog rice of potatoes, cassava flour, and carrots do [16], while ones in purple sweet potatoes and white bread is 67 [17]. Referring to [6] studies, the starch extracted from purple Dioscorea alata and yellow ones grown in Jambi Province, Indonesia have different physical properties - starch of purple bulb has lower swelling power but higher solubility compared to the other. The protein content of U-type strains of $D$. alata is relatively higher compared to other tuber plants, which is a useful dietary nutrient [7]. It is even mentioned that diosgenin and aglycone, chemicals found in Dioscorea, are used commercially in pharmaceutical industry [8]. There are other types of $D$. alata that need more in-depth study. 
Despite its benefits and potentials for agricultural development, "uwi" is getting rare. Fearing that its God-gifted genetic source (germplasm) should extinct in near future, efforts to conserve it - as well as other carbohydrate source plants - should be engaged. Their strategic values for long-term food security must be priceless, considering how the population continues to increase contradicting the decreasing agricultural land both quantitatively and qualitatively. Therefore, it is necessary to research "uwi" for the purpose of exploring, identifying, and preserving its germplasm to make future food security real.

\section{Materials and methods}

\subsection{Place and time}

The research was conducted in December 2016 to July 2017, located in the experimental station which is the property of the Faculty of Agriculture of Merdeka University of Madiun, East Java, Indonesia.

\subsection{Materials and tools}

The materials used in this research are tuber results of the previous year's observation, media of soil planting and fertilizer, and pesticide. The equipment used includes various observation tools consisting of a color chart, roll meter, scales, and data recording equipment.

\subsection{Experimental design}

The previous year's observation has 127 result sample collection, taken from five districts of the ex-residential area of Madiun, East Java, Indonesia, consisting of five groups of Dioscorea species in descending quantity order D. alata, D. aculeata, D. hispida, $D$. pentaphylla, and D. bulbifera. Each of these samples was planted in a planter bag using the same media. The research employed Complete Randomized Design with three replications. Observations were conducted towards the main botanical characteristics including leaf shape, leaf color, leaf base color, thorn stem, aerial tubers, shoot color, tuber shape, branch tuber, tuber skin color, and tuber color.

\subsection{Data analysis}

Samples were distinguished by alata species (D. alata) and non-alata species (D. pentaphylla, D. aculeata, D. hispida, and D. bulbifera), and data obtained were analyzed using SPSS cluster analysis to see the proximity of one sample to another. The analyses were based on the main distinguishing characters mentioned above.

\section{Result and discussion}

From observing "uwi" crops in five regencies of ex-residency of Madiun, 127 variants were noted. The most variants were found in Pacitan district, followed by Madiun, Ponorogo, Magetan, and Ngawi. This indicates that the higher the district is, the more types of "uwi" grow. It was also found that "uwi" was rarely cultivated by farmers, and some 
variants were even difficult to obtain in some places. Apparently, farmers in some areas of Java and Sumatra prefer cultivating cassava, sweet potato, and taro [14].

After planting under controlled land conditions, the results of the identification showed that of the five species found, D. alata species has the most variants. It is presumably due to its good taste, a trait of white tubers, that this species is fairly likeable.

The data were then clustered into two groups - alata and non-alata - since the first group varied more than the latter. Generally, they are quite easy to distinguish from their winding directions, the shape of their leaves, the shape of their tubers, and the existence of stem thorns. This study has discovered that 20 variants in alata group produced much larger bulb yields in sizes, indicating that they contain rich germplasm potential to food provision.

The classification using SPSS software resulted in plant grouping as in Figures 1-4. In Figure 1, the dendrogram shows how 20 variants of $D$. alata taken from five different areas are organized into seven clusters, mainly characterized by their bulb shapes and bulb colors, which is estimated to be due to different nutrient contents in each type. Further information regarding the seven clusters is detailed in Figure 2.

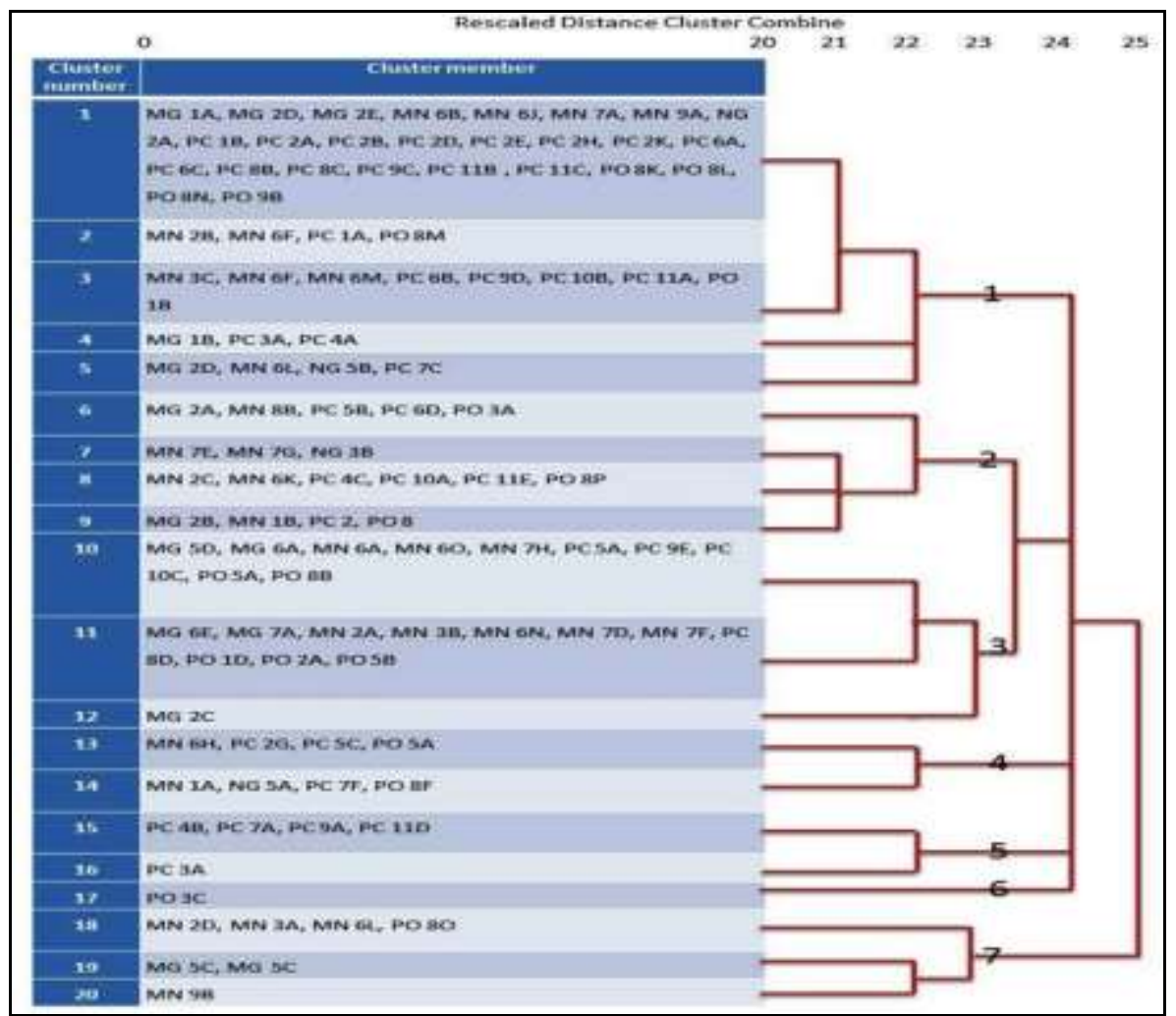

Fig. 1. Dendogram of D. alata group (modified)

Notes. MN: Accession from Madiun, PO: Accession from Ponorogo, PC: Accession from Pacitan, MG: Accession from Magetan, NG: Accession from Ngawi. 


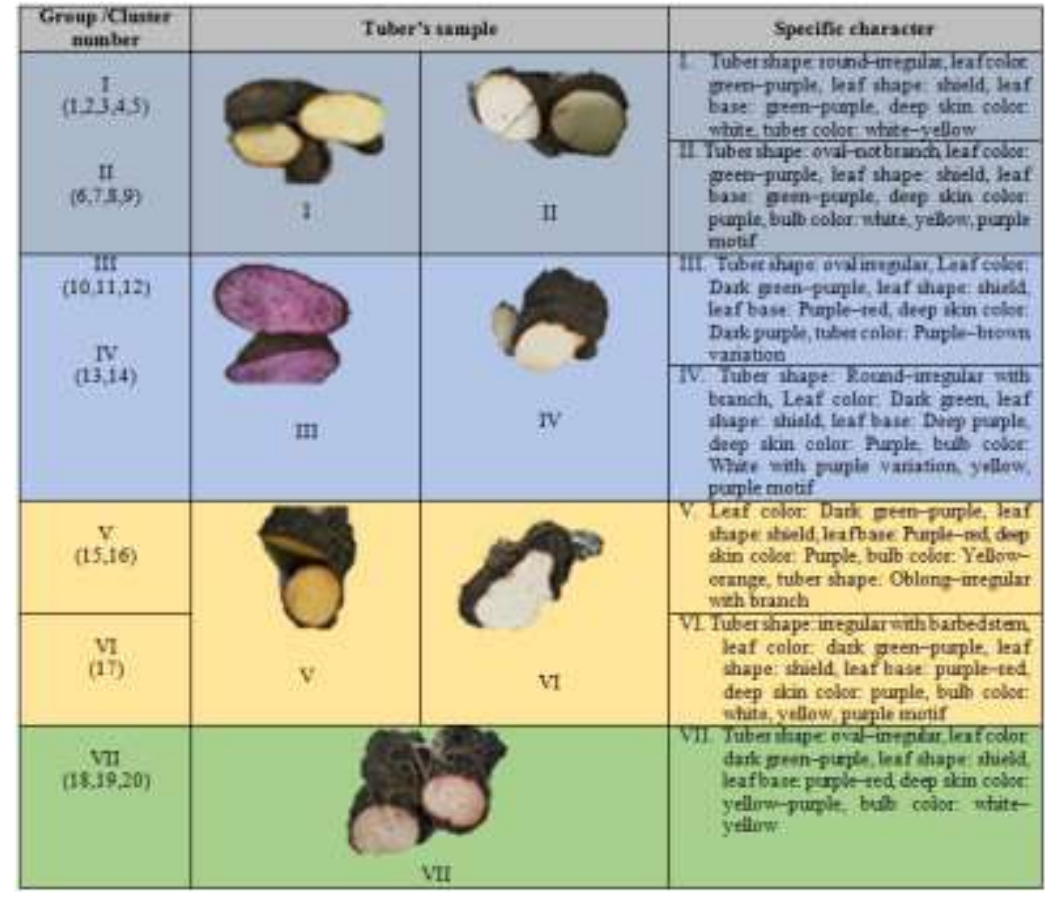

Fig. 2. Characteristics of seven clusters of D. alata

A similar case occurred in clusters II, III, IV and VII, which is the difference is due to different nutrients in each type. Characteristics of cluster V are only found only in Pacitan, and ones of group VI are only found in Ponorogo. Above evidences indicate that variants obtained from aforementioned regions are actually related to ones researched by Trimanto regarding "uwi" in Nganjuk, another region in East Java, Indonesia [9].

As for non-alata group, 22 variants are organized into D. aculeata, D. hispida, D. Pentaphylla, and D. Bulbifera - Figure 3 shows its dendogram in clusters. Out of all clusters, D. aculeata (cluster I) is the largest one, characterized by shape, number, and size of tubers. A bunch of fewer than five larger, round-shaped bulbs belong to Gembolo, while smaller five-or-more bulb bunches go with Gembili (thus the two sub-clusters). Gembili are then further set apart to be Gembili Brul for the smaller tubers and Gembili Teropong for the bigger ones. Specifically for Gembolo, it is also characterized by the number of thorns both on the stem and roots. Another indication of this cluster is that the wider the leaf is, the larger the tuber will be. D. hispida (Gadung) was not found in the assessed collection and put into one separated cluster. D. pentaphylla (Uwi Katak) has two subclusters characterized by not only size and shape of tubers but also origins. Bulbifera (Uwi Gandul), despite difference in origins, is in one same cluster due to their similarities. Points above ground the detailing in Figure 4. 


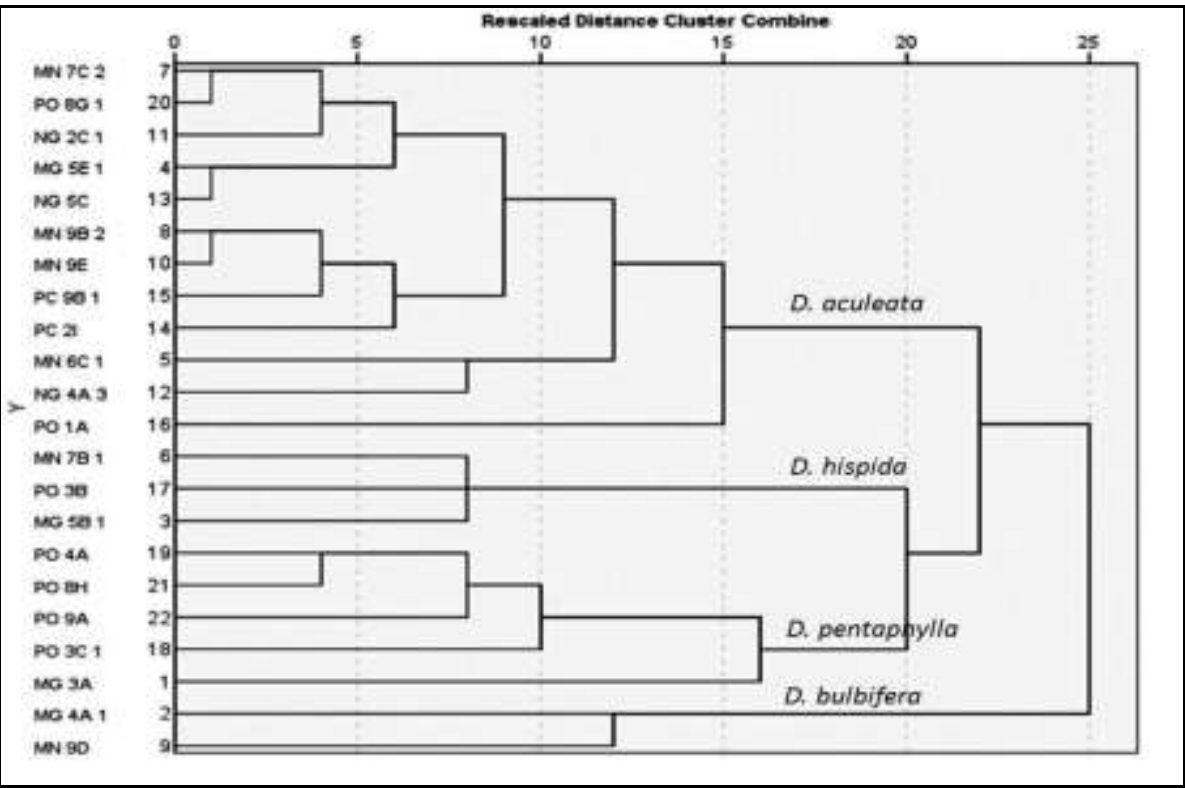

Fig. 3. Dendrogram of non-alata group

Notes: MN : Accession from Madiun, PO : Accession from Ponorogo, PC : Accession from Pacitan, MG : Accession from Magetan, NG : Accession from Ngawi

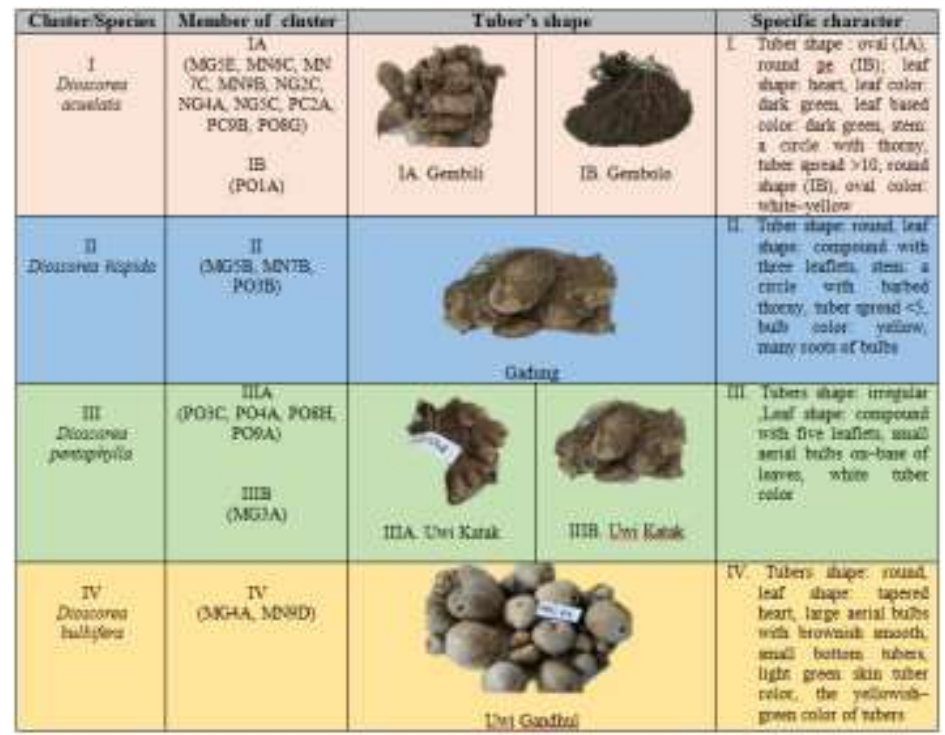

Fig. 4. Characteristic of D. aculeata, D. hispida, D. pentaphylla and D. bulbifera.

\section{Conclusions}

From the analyses presented, it is conclusive that "uwi", with a vast variants available locally and rich in carbohydrates, is a strong candidate to support national food diversification. When strategically developed, it should contribute well in sustaining food provision along with other commodities. Since the government's policy is proven to be 
essential in increasing rice productivity, one to expand access to credit markets for "uwi" farmers is also key to implementing food security programs. Efforts to manage "uwi" effectively and efficiently are also key to sustainable food security, and it calls for further role of education in nutrition and disease studies more effectively and more efficiently.

The authors would like to express their gratitude to DRPM Kemenristekdikti for funding this study under Contract Number 034/SP2H/K2/KM/2017. The authors would also like to thank the Rector of Merdeka University of Madiun, East Java, Indonesia as well as the Dean of the Faculty of Agriculture and all team members and students for all the supports.

\section{References}

[1] Kementerian Lingkungan Hidup dan Kehutanan Republik Indonesia. Statistik kementrian lingkungan hidup dan kehutanan [Statistics of the ministry of environment and forestry]. Pusat data infomasi Jakarta. p. 1-20(2015). [in Bahasa Indonesia]. [Online]

from https://scholar.google.com/scholar?q=Kementerian+Lingkungan + Hidup + dan + Kehuta nan+Republik+Indonesia $+2015+$ Statistik + kementrian+lingkungan + hidup + dan + kehut anan $+\% 28$ Jakarta\%3A+Pusat+data+infomasi+Jakarta\%29+1-20 (2015). [Accessed on October 2018].

[2] M. Noer. Int. J. Adv. Sci. Eng. Inf. Technol. 6,3:277-280(2016). https://www.researchgate.net/profile/Melinda_Noer/publication/304455451_Bridging _Food_Security_and_Agriculture_Development_through_Regional_Planning/links/5d $\underline{82 \mathrm{cae} 0458515 \mathrm{cbd} 1984204 / \text { Bridging-Food-Security-and-Agriculture-Development- }}$ through-Regional-Planning.pdf

[3] E. Wicaksono. Int. J. Adv. Sci. Eng. Inf. Technol. 4,5:322-325(2014). https://doi.org/10.18517/ijaseit.4.5.427

[4] M. Aslam, S. Rasool. Int. J. Adv. Sci. Eng. Inf. Technol. 4,3:19-23(2014). https://doi.org/10.18517/ijaseit.4.3.388

[5] A.D. Santoso, Warji, D.D. Novita, Tamrin. J. Tek. Pertan. Lampung. 2,1: 27-34(2013). [in Bahasa Indonesia]. http://jurnal.fp.unila.ac.id/index.php/JTP/article/viewFile/143/151

[6] Ulyarti, Lavlinesia, D. Fortuna, Surhaini. Int. J. Adv. Sci. Eng. Inf. Technol. 6,4: 456-459(2016).

https://www.researchgate.net/publication/307850296_The_Study_of_PhysicoChemical_Properties_of_Dioscorea_alata's_Starch_From_Jambi_Province

[7] F.D. Baah, B. Maziya-Dixon, R. Asiedu, I. Oduro, W.O. Ellis. J. Food Agric. Environ. 7,2:373-378(2009). http://dspace.knust.edu.gh/bitstream/123456789/9766/1/Nutritional\%20and $\%$ 20Biochemical\%20composition\%20of\%20D.\%20alata.pdf

[8] B. Dutta. J. Pharmacogn. Phytochem. 3,4:15-18(2015). http://www.phytojournal.com/archives/2015/vol3issue5/PartA/7.1.pdf

[9] N. Verter, V. Becvarova. Eur. Sci. J. 10,31:27-42(2014). https://www.researchgate.net/publication/269992864_Yam_Production_as Pillar_of_Food_Security_in_Logo_Local_Government_Area_of_Benue_State_Nigeri $\underline{\mathrm{a}}$ 
[10] A.G. Ironkwe, R. Asiedu. African J. Root Tuber Crop. 11,1:56-64(2014). https://scholar.google.co.id/scholar?hl=id\&as_sdt= $02 \mathrm{C} 5 \& \mathrm{q}=$ Women+Farmers + in + Seed+Yam+Production $\%$ E2\% $80 \% A F \% 3 \mathrm{~A}+$ Implication+for+Increased+Productivity + and + Sustainable + Yam + Improvement + in + Southeastern + Nigeria\&btnG $=$

[11] F.O. Tobih, L.U. Okonmah, A.A. Omoloye. Int. J. AgriScience. 1,3:178-184(2011). https://www.cabdirect.org/cabdirect/abstract/20123239776

[12] A.M.N. Benjamin. Eur. J. Res. Soc. Sci. 2,3:1-9(2014). https://www.idpublications.org/wp-content/uploads/2014/08/AN-EVALUATION-OFFARMERS\%E2\% $80 \% 99$-ADOPTION-OF-YAM-MINI-SETT-TECHNIQUE-INCROSS-RIVER-STATE-NIGERIA.pdf

[13] J.T. Omojola. Adv. J. Agric. Res. 2,6:99-103(2014). https://fliphtml5.com/ocso/wdjl/basic

[14] E.N. Ellong, C. Billard, D. Pétro, S. Adenet, K. Rochefort. J. Exp. Biol. Agric. Sci. 3,2:139-150(2015).

https://www.researchgate.net/publication/275723386_Physicochemical_nutritional_an d_sensorial_qualities_of_Boutou_Yam_Dioscorea_alata_varieties

[15] Wuryantoro, R.M. Wardhani, I.R. Pupitawati. Plasma nutfah tanaman Uwi, karunia Tuhan yang harus diselamatkan [Germplasm uwi plant, God's gift that must be saved]. Prosiding Seminar Hasil Penelitian Tahun 2017. p. 1-20(2017). [in Bahasa Indonesia].

https://scholar.google.com/scholar?q=Wuryantoro $\% 2 \mathrm{C}+$ Wardhani+R.+M.+and + Rekyani+I.+2017+Plasma+Nutfah+Tanaman+Uwi\%2C+Karunia+Tuhan+Yang+Har us+Diselamatkan+Prosiding + Seminar+Hasil + Penelitian+Tahun $+2017+$ $\underline{1-20}$

[16] T. Anggraini, V.J. Putri, Neswati, Yuliani. Int. J. Adv. Sci. Eng. Inf. Technol. 6,5:723(2016). http://insightsociety.org/ojaseit/index.php/ijaseit/article/view/762/pdf_257

[17] E. Aritonang, A. Siagian, F. Izzati. Int. J. Adv. Sci. Eng. Inf. Technol. 7,2: 580-586(2017).

https://www.researchgate.net/publication/316986520_Mixed_cooked_rice_with_purpl e_sweet_potato_is_potential_to_be the _low_glycemic_index_food_and_staple_food alternative 